\title{
Analyzing the Determinants of Disclosures of Sustainability Report on LQ45 Companies
}

\author{
Muhammad Khafid ${ }^{1}$, Niswah Baroroh ${ }^{2}$, Tusyanah Tusyanah ${ }^{3}$, Vivi Ayuning Tyas ${ }^{4}$ \\ \{muh_khafid@mail.unnes.ac.id ${ }^{1}, \underline{\text { niswahbaroroh@mail.unnes.ac.id }}{ }^{2}$, tusyanah@mail.unnes.ac.id ${ }^{3}$, \\ viviayuningtyas2@gmail.com $\left.{ }^{4}\right\}$ \\ ${ }^{1234}$ Universitas Negeri Semarang, Accounting Department, Faculty of Economics,
}

\begin{abstract}
The objective of the study are to analyze the effects of profitability, leverage, and company size and company growth on disclosure of sustainability report and to examine the role of corporate governance as the moderating variable for the effects of profitability and leverage on disclosure of sustainability report. The research populations were companies consistently indexed by LQ45. The samples were taken by purposive sampling and got 51 units of analysis. The data were analyzed by regression. The results showed that profitability, leverage and company growth did not influence the disclosure of sustainability report. Then, company size had a negative effect on disclosure of sustainability report. Next, corporate governance moderated successfully the relationship of profitability and leverage on the disclosure of sustainability report. Thus; it is concluded that company size had a negative effect on sustainability report disclosure and corporate governance had a moderating role for the effect of profitability and leverage on disclosure of sustainability report. The novelty of the study is putting board of commissioners as the moderating variable. It is to analyze the joint effects of independent variables on sustainability report disclosure.
\end{abstract}

Keywords: Corporate Governance, Firm Growth, Firm Size, Leverage, Profitability, Sustainability Report.

\section{Introduction}

The goal of the company that refers to the single P paradigm (profit) has turned into a triple bottom line paradigm developed by Elkington (1998). Dilling (2010) states that companies expecting the sustainability should pay attention to increase company income/ profit, to provide welfare to employees and the community, and the earth to maintain and improve the quality of nature where the company operates[1]. Sustainability report is very important for the company because it can be a measure of achievement of work targets which is fit with the triple bottom line. Sustainability report provides many benefits for the company, such as; improving company transparency, improving stakeholder relations, attracting long-term capital, generating an investment climate that benefits and maintains the company's reputation (Bhatia \& Tuli, 2017) [2].

On the basis of the triple bottom line concept, the company is expected to contribute to the economic, social and environmental sectors. However, cases of environmental damage triggered by company business activities still happen frequently. In fact, mining company operations contribute up to $70 \%$ of environmental damage in Indonesia. Environmental damage reflects the company's low responsibility to the environment. The research conducted by Rudyanto \& Siregar 
(2018) [3]which examined 123 sustainability reports on companies listed on the Indonesia Stock Exchange in 2010-2014 found that the quality of sustainability reports in Indonesia was still low. It is indicated by the low number of opinions on sustainability reports and independent party assessments regarding the GRI Application Check. Environmental damage and the low sustainability report disclosure show that the company's social and environmental responsibilities are still low.

The previous studies on the factors influencing sustainability report disclosure got the inconsistent results which created the research gap. The studies done by Legendre \& Coderre (2013) [4], Martínez-Ferrero et al. (2015) [5], and Nazari et al. (2015) [6] stated that profitability had the positive effect on sustainability report disclosure. It is different with studies done by Shamil et al. (2014), Andrikopoulos et al. (2014), and Karaman et al. (2018) which stated that profitability did not have any effect on sustainability report disclosure.

Then, the studies done by Drobetz et al. (2014) [7], Bhatia \& Tuli, (2017), dan Kuzey \& Uyar (2017) [8] found that leverage had a negative effect on sustainability report disclosure. On the other hand; Martínez-Ferrero et al. (2015), Nazari et al. (2015), and Hussain et al. (2018) [9] found that leverage did not have any effect on sustainability report disclosure.

Furthermore; the studies conducted by Bhatia \& Tuli (2017), and Karaman et al. (2018)[10] showed that firm size had a positive effect on sustainability report disclosure. On the other hand, the results of Dilling (2010) and Lungu et al. (2011)[11] found that firm size did not affect sustainability report disclosure.

Then, the studies conducted by Shamil et al., (2014),[12] and found that company growth had a positive effect on sustainability report disclosure. However, Kuzey \& Uyar (2017) dan Karaman et al., (2018) found that company growth did not affect sustainability report disclosure.

The objective of the study is to determine the factors which influence sustainability report disclosure. The factors of the study are profitability, leverage, firm size, and company growth which the results of previous studies of these factors are still inconsistent. These inconsistent results are considered to be triggered by other variables which also influence the relationship of these variables with sustainability report disclosure.

The study uses corporate governance as a moderating variable. The moderating variable is expected to see the role of moderation on the effect of profitability, leverage, firm size, and company growth on sustainability report disclosure.

The selection of corporate governance is based on the idea that the goal of corporate governance practices is the fulfillment of corporate objectives by taking into account the interests of stakeholders. Disclosures of sustainability report are used by the company with the goal of fulfilling the information needs of stakeholders which include the company's responsibility to the economy, social, and environment. Through the practice of corporate governance, the company is expected to disclose the sustainability report as a fulfillment of broad information needs.

The theories used to explain sustainability report disclosure are stakeholder theory and legitimacy theory. Stakeholder theory shows that managers should formulate and implement processes that satisfy all groups which have interests in business. Managers are tasked with managing and integrating the relationships and interests of shareholders, employees, customers, suppliers, communities and other groups in ways that ensure long-term corporate success (Freeman \& Mcvea, 2001)[13]. Legitimacy theory states that companies try to create harmony between the social values inherent in their activities and norms of behavior that exist in the social system of society. Legitimate theory emphasizes on perception and public recognition as the main forces for disclosing information (Khafid et al. 2018)[14]. Here they are the hypotheses of the study:

H1: Profitability has a positive effect on Disclosures of sustainability report 
H2: Leverage has a negative effect on Disclosures of sustainability report

H3: Firm size has a positive effect on Disclosures of sustainability report

H4: Company growth has a positive effect on Disclosures of sustainability report

H5: The board of commissioners moderates the effect of profitability on Disclosures of sustainability report

H6: The board of commissioners moderates the influence of leverage on Disclosures of sustainability report

\section{Methods}

It is a quantitative research. The population of the study are companies which are consistently LQ45-indexed for the period of 2015-2017, there are 40 companies. The samples are selected using a purposive sampling technique and get 17 companies with three years period of observation to get 51 analysis units.

The explanation of each variable is presented at Table 1 as follows:

Table 1. Operational Definitions of the Research Variables

\begin{tabular}{|c|c|c|c|}
\hline $\mathrm{No}$ & Variables & Definitions & Measurements \\
\hline 1. & $\begin{array}{l}\text { Sustainability } \\
\text { Report } \\
\text { Disclosure } \\
\text { (SR) }\end{array}$ & $\begin{array}{l}\text { Report which provides information } \\
\text { about environmental and social } \\
\text { corporate responsibility (Khafid \& } \\
\text { Mulyaningsih, 2015)[15] }\end{array}$ & $\begin{array}{l}\left(\sum \text { Item Disclosed)/ }\right. \\
\text { (Item GRI) }\end{array}$ \\
\hline 2. & $\begin{array}{l}\text { Profitability } \\
\text { (ROE) }\end{array}$ & $\begin{array}{l}\text { The company's ability to generate } \\
\text { profits is also seen as one indicator } \\
\text { of good corporate management } \\
\text { (Khafid \& Mulyaningsih, 2015) }\end{array}$ & $\begin{array}{l}\text { ROE }= \\
\text { (Net Income)/ } \\
\text { (Total Equity) }\end{array}$ \\
\hline 3. & $\begin{array}{l}\text { Leverage } \\
\text { (DAR) }\end{array}$ & $\begin{array}{l}\text { Contribution of owners (investors or } \\
\text { shareholders) compared to funds } \\
\text { originating from creditors (Khafid \& } \\
\text { Mulyaningsih, 2015) }\end{array}$ & $\begin{array}{l}\text { DAR }= \\
\text { (Total Debt)/ } \\
\text { (Total Asset) }\end{array}$ \\
\hline 4. & $\begin{array}{l}\text { Firm size } \\
\text { (SIZE) }\end{array}$ & $\begin{array}{l}\text { Firm size is the size illustration of a } \\
\text { company divided into three } \\
\text { categories: large, medium and small } \\
\text { companies (Khafid et al., 2018) }\end{array}$ & Ln (Total Asset) \\
\hline 5. & $\begin{array}{l}\text { Company } \\
\text { Growth } \\
\text { (GROWTH) }\end{array}$ & $\begin{array}{l}\text { The impact of the company's cash } \\
\text { flow from operational changes } \\
\text { triggered by an increase or growth } \\
\text { in business volume (Khafid et al., } \\
2018 \text { ) } \\
\text { (Khafid et al., 2018) }\end{array}$ & $\begin{array}{l}\left(\mathrm{TA}+\mathrm{t}-\mathrm{TA} A_{-}(\mathrm{t}\right. \\
-1)) / \mathrm{TA}_{-}(\mathrm{t}-1)\end{array}$ \\
\hline 5 & $\begin{array}{l}\text { Corporate } \\
\text { Governance } \\
\text { (DK) }\end{array}$ & $\begin{array}{l}\text { The board of commissioners as a } \\
\text { corporate governance organ having } \\
\text { the duty to oversee management in } \\
\text { order to make sure that the act is fit } \\
\text { with the interests of stakeholders } \\
\text { (Rudyanto \& Siregar, 2018) }\end{array}$ & $\begin{array}{l}\text { Number of board of } \\
\text { commissioner } \\
\text { meetings in one } \\
\text { period }\end{array}$ \\
\hline
\end{tabular}

Source: The processed various references, 2019 
The research data are collected by the documentation method for getting the annual reports and sustainability reports. Technical data analysis uses regression with moderating variables. The classic assumption tests. The research model is formulated as follows:

$$
\mathrm{SR}=\alpha+\beta 1 \mathrm{ROE}-\beta 2 \mathrm{DAR}+\beta 3 \mathrm{SIZE}+\beta 4 \mathrm{GROWTH}+\beta 5|\mathrm{ROE}-\mathrm{DK}|+\beta 6 \mid \mathrm{DAR}-
$$

$$
\mathrm{DK} \mid(1)
$$

\section{Results and Discussion}

The results of the descriptive statistical analysis are presented in Table 2.

Table 2. Results of Descriptive Statistics Analysis

\begin{tabular}{lrccc}
\hline & $\mathrm{N}$ & Minimum & Maximum & Mean \\
\hline SR & 51 & 0.03297 & 0.95604 & 0.3289064 \\
ROE & 51 & -0.07866 & 0.32951 & 0.1177700 \\
DAR & 51 & 0.13306 & 0.91933 & 0.5419984 \\
SIZE & 51 & 30.35252 & 34.65767 & 32.1379967 \\
GROWTH & 51 & -0.07152 & 0.58636 & 0.1357391 \\
DK & 51 & 4.0 & 51.0 & 17.137 \\
Valid N (listwise) & 51 & & & \\
\hline
\end{tabular}

Source: SPSS Output, 2019

The adjusted R2 value is 0.243 ; it means that profitability, leverage, firm size, and corporate governance as the moderating variable explain $24.3 \%$ sustainability report disclosure. $75.7 \%$ were explained by variables not tested in the study. The results of hypotheses testings can be seen at table 3.

\begin{tabular}{|c|c|c|c|c|c|}
\hline \multicolumn{2}{|c|}{ Hypotheses } & \multirow{2}{*}{$\begin{array}{l}\begin{array}{l}\text { Koef. } \\
\text { Regresi }\end{array} \\
-0.249\end{array}$} & \multirow{2}{*}{$\begin{array}{l}\text { t- } \\
\text { Count } \\
- \\
0.663\end{array}$} & \multirow{2}{*}{$\frac{\text { Sig }}{0.511}$} & \multirow{2}{*}{$\frac{\text { Results }}{\text { Rejected }}$} \\
\hline$\overline{\mathrm{H} 1}$ & $\begin{array}{l}\text { Profitability has a positive effect on } \\
\text { sustainability report disclosure }\end{array}$ & & & & \\
\hline $\mathrm{H} 2$ & $\begin{array}{l}\text { Leverage has a negative effect on } \\
\text { sustainability report disclosure }\end{array}$ & 0.250 & 1.313 & 0.196 & Rejected \\
\hline H3 & $\begin{array}{l}\text { Firm size has a positive effect on } \\
\text { sustainability report disclosure }\end{array}$ & -0.072 & - & 0.019 & Rejected \\
\hline $\mathrm{H} 4$ & $\begin{array}{l}\text { The company's growth has a positive } \\
\text { effect on sustainability report disclosure }\end{array}$ & -0.074 & $-\overline{0}-324$ & 0.748 & Rejected \\
\hline H5 & $\begin{array}{l}\text { The board of commissioners moderates } \\
\text { the effect of profitability on Disclosures } \\
\text { of sustainability report }\end{array}$ & 0.093 & 2.923 & 0.006 & Accepted \\
\hline H6 & $\begin{array}{l}\text { The board of commissioners moderates } \\
\text { the influence of leverage on Disclosures } \\
\text { of sustainability report }\end{array}$ & -0.206 & $-\overline{2} \cdot 701$ & 0.10 & Accepted \\
\hline
\end{tabular}

Table 3. Summary of Hypotheses Testing Results

Source: Processed secondary data, 2019 
The results shows that profitability does not affect sustainability report disclosure (H1 is rejected). The results of the study are not in line with stakeholder theory which states that companies should be able to meet the expectations and interests of stakeholders, including in terms of providing extensive information. On the basis of stakeholder theory, companies with high profitability will disclose extensive information, including sustainability report disclosure. It is because the survival of the company is influenced by the stakeholders' support and trust (Doktoralina et al., 2018).[16]

The high and low profitability of the company does not become a benchmark for sustainability report disclosure. Companies in generating profits can come from activities which have a negative impact on social and environment, so companies prefer not to disclose the sustainability report (Aniktia \& Khafid, 2015)[17]. Furthermore, when profitability is low, companies may not feel the pressure to disclose extensive information (Karaman et al., 2018). Consequently; it is not encouraged the company to disclose the sustainability report. The results of the study support the research conducted by Shamil et al. (2014), Andrikopoulos et al. (2014),[18] and Karaman et al. (2018).

The result shows that leverage does not affect sustainability report disclosure ( $\mathrm{H} 2$ is rejected). Companies which have a high degree of leverage disclose the extensive information to meet the information needs of stakeholders by disclosing the sustainability reports (Khafid \& Mulyaningsih, 2015). The extensive information can be used to eliminate creditor doubts about fulfilling company obligations to creditors. Naser et al. (2006) in Karaman et al., (2018) argued that companies with high leverage are risky companies which make them difficult to access finance from banks or stock markets if the company does not disclose extensive information about the company's business activities. The results of the study support the research conducted by Martínez-Ferrero et al. (2015), Nazari et al. (2015), and Hussain et al. (2018).

The result shows that firm size has a significant negative effect on sustainability report disclosure (H3 is rejected). Large companies do not consider to disclose extensive information to gain legitimacy because the existence of large companies can maintain business existence. It means that the company has actually been recognized by the public. Then, small companies which disclose the sustainability report; it is a form of communication if the company has added value and potential value to act towards a sustainable future (Massa et al.2015)[19]. The result of the study is in line with the research conducted by Isa (2014).[20]

The result shows that the growth of the company does not affect sustainability report disclosure (H4 was rejected). The company's growth does not affect the sustainability report disclosure because the total assets of the company are not a benchmark for carrying out corporate responsibility (Lucyanda \& Siagian, 2012)[21]. Even though the company has negative growth, the company is able to disclose the sustainability report as long as it has enough assets to finance (Khafid et al., 2018).

Karaman et al., (2018) argued that there was no significant relationship between company growth and sustainability report disclosure because companies with high growth might not disclose additional information through sustainability reports to avoid ownership costs. The result of the study supported the research conducted by Lucyanda \& Siagian (2012), Kuzey \& Uyar (2017), and Karaman et al., (2018)

The result shows that the board of commissioners significantly moderated the effect of profitability on disclosures of sustainability report (H5 is accepted). It is in line with the opinion of Khafid et al. (2018) that companies with good governance practices can disclose information about disclosure of responsibility for company activities, particularly regarding sustainability reports. The board of commissioners as one of the corporate governance structures is tasked with 
overseeing management in order to act is fit with the interests of stakeholders (Rudyanto \& Siregar, 2018).

The result shows that the board of commissioners significantly moderates the effect of leverage on sustainability report disclosure (H6 is accepted). On the basis of stakeholder theory, the board of commissioners will ensure that all stakeholder interests can be met. The extensive information disclosure is one proof of the company's transparency to stakeholders. Transparency is considered as the main element in good corporate governance carried out through reporting practices that ensure stakeholders comply with what happens to the company (Amran \& Ooi, 2014)[22].

\section{Conclusion}

The results of the study show that profitability, leverage, and company growth do not have any effect on sustainability report disclosure. Firm size has a negative effect on sustainability report disclosure. The board of commissioners significantly moderates the effect of profitability and leverage on sustainability report disclosure. The study finds the level of sustainability report disclosure in Indonesia is still low with an average disclosure for only $32 \%$. The company is expected to pay attention to corporate governance practices so information needs through sustainability reports can be fulfilled. It is suggested for further research to consider the type of company because not all companies have activities related to the environment. 


\section{References}

[1] Dilling, P. F. A. : Sustainability Reporting In A Global Context: What Are The Characteristics Of Corporations That Provide High Quality Sustainability Reports An Empirical Analysis. International Business \& Economics Research Journal (IBER). Vol 9 (1), 19-30 (2010)

[2] Bhatia, A., \& Tuli, S. : Corporate attributes affecting sustainability reporting: an Indian perspective. International Journal of Law and Management. Vol 59 (3), (2017)

[3] Rudyanto, A., \& Veronica Siregar, S. : The effect of stakeholder pressure and corporate governance on the sustainability report quality. International Journal of Ethics and Systems. Vol 34(2), 233-249 (2018)

[4] Legendre, S., \& Coderre, F. : Determinants of GRI G3 Application Levels: The Case of the Fortune Global 500. Corporate Social Responsibility and Environmental Management, 20(3), 182-192 (2013)

[5] Martínez-Ferrero, J., Garcia-Sanchez, I. M., \& Cuadrado-Ballesteros, B. : Effect of financial reporting quality on sustainability information disclosure. Corporate Social Responsibility and Environmental Management, Vol 22(1), 45-64 (2015)

[6] Nazari, J. A., Herremans, I. M., Warsame, H. A., Nazari, J. A., Herremans, I. M., \& Warsame, H. A. : Sustainability reporting: external motivators and internal facilitators. Corporate Governance, Vol 15(3), 375-390 (2015)

[7] Drobetz, W., Merikas, A., Merika, A., \& Tsionas, M. G. : Corporate social responsibility disclosure: The case of international shipping. Transportation Research Part E: Logistics and Transportation Review, Vol 71, 18-44 (2014)

[8] Kuzey, C., \& Uyar, A. : Determinants of sustainability reporting and its impact on firm value: Evidence from the emerging market of Turkey. Journal of Cleaner Production, Vol 143, 27-39 (2017)

[9] Hussain, N., Rigoni, U., \& Orij, R. P. : Corporate Governance and Sustainability Performance: Analysis of Triple Bottom Line Performance. Journal of Business Ethics, Vol 149(2), 411-432 (2018)

[10] Karaman, A. S., Kilic, M., \& Uyar, A. : Sustainability reporting in the aviation industry: worldwide evidence. Sustainability Accounting, Management and Policy Journal, Vol 9(4), 362-391 (2018)

[11] Lungu, C. I., Caraiani, C., \& Dascălu, C. : Research on corporate social responsibility reporting. Amfiteatru Economic, 13(29), 117-131 (2011)

[12] Shamil, M. M., Shaikh, J. M., Ho, P. L., \& Krishnan, A. : The influence of board characteristics on sustainability reporting Empirical evidence from Sri Lankan firms. Asian Review of Accounting, Vol 22(2), 78-97 (2014)

[13] Freeman, R. E., \& Mcvea, J. F. : A Stakeholder Approach to Strategic Management Darden Graduate School of Business Administration University of Virginia Working Paper No . 01-02 A Stakeholder Approach to Strategic Management (2001)

[14] Khafid, M., Baroroh, N., \& Firmansyah, M. : The Role of Corporate Governance in Moderating the Influence of Company Growth and Size on Corporate Social Responsibility Disclosure. International Conference on Economics, Business and Economic Education 2018. Vol 2018, 2018, $27-45$ (2018)

[15] Khafid, M., \& Mulyaningsih. : Kontribusi Karakteristik Perusahaan Dan Corporate Governance Terhadap Publikasi Sustainability Report. Ekuitas: Jurnal Ekonomi Dan Keuangan, Vol 19(3), 340-359 (2015)

[16] Doktoralina, C. M., Anggraini, D., \& Melzatia, S. : The Importance of Sustainability Reports In NonFinancial Companies. Jurnal Akuntansi, XXII(03), 368-384 (2018)

[17] Aniktia, R., \& Khafid, M. : Pengaruh Mekanisme Good Corporate Governance dan Kinerja Keuangan terhadap Pengungkapan Sustainability Report. Accounting Analysis Journal, Vol 4(3), 1-10 (2015)

[18] Andrikopoulos, A., Samitas, A., \& Bekiaris, M. : Corporate social responsibility reporting in financial institutions: Evidence from Euronext. Research in International Business and Finance, Vol 32, 27-35 (2014)

[19] Massa, L., Farneti, F., \& Scappine, B. : Developing a Sustainability Report in a Small to Medium Enterprise: Process and Consequnces. Meditari Accountancy Research, Vol 23(1), 62-91 (2015)

[20] Isa, M. A. : Sustainability Reporting among Nigeria Food and Beverages Firms. International Journal of Agriculture and Economic Develpoment, 2(June), Vol 1-9 (2014)

[21] Lucyanda, J., \& Siagian, L. G. P. : The influence of Corporate characteristics on Corporate Social Responsibility Disclosure. The 2012 International Conference on Business and Management, 601-619 (2012) 
[22] Amran, A., \& Ooi, S. K. : Sustainability reporting: Meeting stakeholder demands. Strategic Direction, 30(7), 38-41 (2014) 